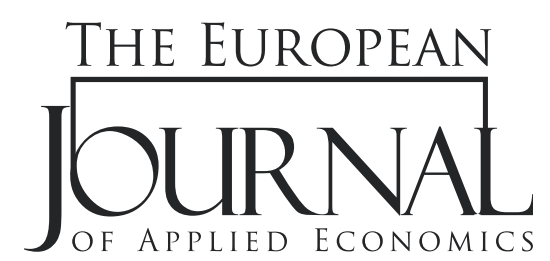

EJAE 2020, 17(1): 1 - 19

ISSN 2406-2588

UDK: 338.432:330.322.5(497.113)

336.226.14

DOI: 10.5937/EJAE17-21368

Original paper/Originalni naučni rad

\title{
DETERMINANTS OF PROFITABILITY OF THE AGRICULTURAL SECTOR OF VOJVODINA: THE ROLE OF CORPORATE INCOME TAX
}

\author{
Stefan Vržina*, Miloš Dimitrijević \\ Faculty of Economics, \\ University of Kragujevac, \\ Serbia
}

\begin{abstract}
:
Due to considerable share in total employment and foreign trade exchange, agriculture represents an important sector of the Serbian economy. It is, therefore, necessary to continuously analyze the financial performance of agricultural companies and key determinants of financial performance. The objectives of this paper are to analyze the corporate income tax burden of agricultural companies in Vojvodina, as well as its impact on company profitability. Statistical tests showed that effective corporate income tax rates (ETRs) in agricultural companies are significantly lower than the statutory corporate income tax rate. Furthermore, nearly $69 \%$ of observations have both a current ETR and cash ETR of $0 \%$, which indicates that agriculture is an industry with an exceptionally low corporate income tax burden. Panel regression showed that agricultural companies with lower ETRs are more profitable than companies with higher ETRs. Results of the analysis are not sensitive to changes in corporate income tax burden and profitability proxies.
\end{abstract}

Article info:

Received: April 16, 2019

Correction: December 2, 2019

Accepted: December 4, 2019

\section{Keywords:}

agriculture,

profitability,

corporate income tax,

Vojvodina.

\section{INTRODUCTION}

Despite greater focus on the sector of information and communications technology, the agricultural sector still represents an important part of Serbian economy. Atanasijević and Danon (2014) stress that Serbia has a large agricultural sector, with high-quality arable land and a favorable continental climate. Mitrović, Mitrović, and Cogoljević (2017) argue that the share of agriculture among total employment in Serbia is still significant and that agriculture is a very important factor in the country's foreign trade exchange. On the other hand, agriculture is one the most criticized industries within the context of failed privatization processes (Radulović, \& Dragutinović, 2015, p. 227). Stanojević, Krstić, and Đekić (2015) emphasize the need for a further increase in agricultural production and productivity, primarily through improvement of technological equipment of agricultural companies. Therefore, it is necessary to continuously assess the profitability of agricultural companies in Serbia. 
Companies naturally strive to avoid corporate income tax liabilities in order to become more profitable. Andreoni, Erard, and Feinstein (1998) point out that tax avoidance practices are as old as taxes themselves. However, in practice it is not easy to distinguish between legal tax avoidance and illegal tax evasion. As a result, in theory and practice, a new term is defined - tax avoision - to describe situations in which tax law does not clearly declare the legality of certain tax practices (Prinz, Muehlbacher, \& Kirchler, 2014).

The research subject of this paper is corporate income tax as a determinant of profitability of agricultural companies in Vojvodina. This geographic region was chosen for analysis since (as of December $3^{\text {st }}$ , 2016) nearly $53 \%$ of the agriculture, forestry, and fishing sector companies in Serbia are headquartered in Vojvodina (according to the Statistical Office of the Republic of Serbia, 2017). This research area could be significant, since an imposed moderate flat statutory corporate income tax rate (STR) is 15\% in Serbia, with many options available for the reduction of effective corporate income tax rates (ETR).

There are two main objectives to this paper. The first objective is to measure the corporate income tax burden of agricultural companies in Vojvodina, while the second is to examine whether the profitability of agricultural companies in Vojvodina is significantly influenced by corporate income tax, i.e., whether agricultural companies with lower corporate income tax burdens are more profitable than companies with higher corporate income tax burdens.

Corporate income tax burden and profitability are proxied with many indicators in order to test the sensitivity of results to change of the proxies - corporate income tax burden is proxied with current ETR and cash ETR, while profitability is proxied with ROA (Return on Assets), ROE (Return on Equity), and ROS (Return on Sales).

The impact of corporate income tax on company profitability may seem trivial, since tax expense reduces the income available for reinvestment or distribution to the owners. However, when using current and cash ETR, such impact depends on company tax avoidance strategy. If a company uses temporary book-tax differences to avoid taxes, employed ETRs have no impact on profitability, as deferred corporate income tax expenses offsets reduction in current corporate income tax expense. On the other hand, if a company uses permanent book-tax differences, employed ETRs impact profitability, since deferred corporate income tax expense does not offset permanent differences.

An empirical analysis on the sample of 50 agricultural companies across a four year period was conducted. Considering empirical orientation of the research, inductive approach is dominant in this paper. Furthermore, the following statistical methods were employed: descriptive statistics, tests of equality, correlation analysis, and panel regression analysis.

This study contributes to the relevant literature in several ways. It contributes to the existing literature on the profitability of Serbian agricultural companies, which has been studied from various aspects but not from the tax aspect. In addition, it contributes to the existing foreign literature on the influence of corporate income tax on company profitability.

The originality of the research is reflected in the fact that this is, to authors' knowledge, the first research that includes tax aspects in the analysis of profitability of agricultural companies in Vojvodina. Excepting the introduction, conclusion, and appendix, the paper consists of three parts. The literature review and hypotheses development are given in part 1. Sample description and research model are shown in part 2. Results of the empirical research are given in part 3. 


\section{LITERATURE REVIEW AND HYPOTHESES DEVELOPMENT}

The profitability of agricultural companies in Serbia and other transitional economies has been studied from various aspects in the past decade. Birovljev, Đokić, Matkovski, and Kleut (2017) argue that the performances of the agricultural sector in CEFTA (Central European Free Trade Agreement) countries are far from the performances in the European Union (EU). Jakšić, Zekić, Ristić, and Mijić (2016) find that the profitability of agricultural companies in the EU is considerably higher than the profitability of agricultural companies in non-EU Southeastern European countries, though countryspecific characteristics can be more important determinants of profitability than EU membership.

On the examples of the Slovakian and Hungarian agricultural sector, Chrastinova and Burianova (2009) and Miklos (2014), respectively, argue that EU membership can improve the productivity and profitability of agriculture through Common Agricultural Policy subsidies, although agriculture performances in these countries are still far from its main competitors in Western Europe. Kocsis and Major (2017) argue that Polish, Hungarian, and Czech agricultural sectors suffer from a lack of capital and unfavorable loan conditions, despite EU membership.

Previous research find that the global economic crisis significantly hit the agricultural sector of Serbia and Vojvodina. Zekić, Gajić and Kresoja (2012) find that first decade of the $21^{\text {st }}$ century in Serbia was marked not only by growth in agricultural production and productivity, but by the global crisis as well. Vukoje and Zekić (2010) add that positive trends in the agricultural sector of Vojvodina disappeared in 2008 and 2009, partially due to the global crisis. After that, between 2010 and 2015, agricultural companies from Vojvodina recovered from losses and achieved modest profit rates (Vukoje, \& Dulić, 2017). Bubić and Hajnrih (2012) conclude that the global crisis has only deepened existing problems of bad privatizations of agricultural companies in Vojvodina and its failure to restrict the level of companies' debt.

Vučković (2016) stresses that agricultural companies in Vojvodina, despite having similar arable land and operating in the same same geographic area, might have varying profitability due to differences in their financial structures, asset structures, activity ratios, and liquidity. Vučković, Veselinović, and Vučković (2017) add that higher level of owners' equity in total assets and higher liquidity ratio positively influence the profitability of agricultural companies in Vojvodina.

Vukoje and Vukelić (2010) argue that agricultural companies in Vojvodina are increasingly engaged in trade activities in pursuit of profits. They find that the costs of sold merchandise increase while the costs of production materials decrease in agricultural companies over the years. On the other hand, Mijić and Jakšić (2016) find that trade activities are among the most profitable economic activities in Serbia.

Agricultural companies in Serbia are influenced by several specific factors. Đuričin and Bodroža (2013) point out that drought and other meteorological extremes worsened the profitability of agricultural companies in Serbia between 2007 and 2010. In terms of profitability, Vukoje, Miljatović, and Zoranović (2017) argue that, in Vojvodina, most problems are found among micro and small-sized agricultural companies, while medium and large-sized companies are far more successful.

On the other side, previous research that studied the impact of corporate income tax on the financial performance of the agricultural sector is scarce. Crocker and Slemrod (2005) show abundant evidence that the focus of companies has changed from passive compliance with tax laws to active and often aggressive tax avoidance and tax planning. Furthermore, contemporary companies implement advanced tax strategies that capture their tax expense minimization, compliance requirements, and public demonstrations of "fair" share of taxes paid (Hogsden, 2018).

Agricultural companies studied in this paper follow International Accounting Standards (IAS), International Financial Reporting Standards (IFRS), or IFRS for small and medium-sized enterprises. 
According to these standards, companies report current and deferred corporate income tax in their income statement. Dhaliwal, Gleason and Mills (2004) argue that management of companies can adjust their current and deferred corporate income tax expense in order to maximize profitability of their companies.

Empirical research on the relation between corporate income tax and profitability is relatively scarce since researchers from the most developed countries are primarily interested in the influence of corporate income tax on company value, usually proxied with Tobin's Q. Therefore, the majority of the research on the influence of corporate income tax on profitability have been conducted in developing countries with lower efficiency and liquidity of stock markets.

Previous research predominantly find significant a positive impact of legal minimization of corporate income tax expense on company profitability. Gatsi, Gadzo, and Kportorgbi (2013), Assidi, Aliani, and Omri (2016) and Pitulice, Stefanescu, Minzu, Popa, and Niculescu (2016) studied Ghanaian, Tunisian, and Romanian companies, respectively. They found that corporate income tax is statistically significant determinant of company profitability - a reduction of ETR leads to a significant increase of company profitability. In the context of Serbia, Vržina (2018) studied companies listed on the Belgrade Stock Exchange and found a significant negative impact of ETR on company profitability.

Al-Jafari and Al Samman (2015) studied companies in Oman and found no statistically significant influence of corporate income tax on company profitability. Contrary to economic logic, Ezugwu and Akubo (2014) found that profitability of Nigerian companies increases with an increase in ETR.

It is important to notice that STRs in most of the previously mentioned research (Gatsi et al., 2013; Ezugwo, \& Akubo, 2014; Assidi et al., 2016; Pitulice et al., 2016) were higher than current STR in Serbia (15\%). Moreover, in the research of Al-Jafari and Al Samman (2015) and Assidi et al. (2016) ETR was, on average, lower than STR.

Considering previous research results, the following research hypotheses are formulated:

$H_{1}$ : Effective corporate income tax rate (ETR) in agricultural companies in Vojvodina is significantly lower than statutory corporate income tax rate (STR).

$H_{2}$ : Agricultural companies in Vojvodina with lower effective corporate income tax rate (ETR) are more profitable than agricultural companies with higher ETR.

\section{SAMPLE AND RESEARCH MODEL}

The research sample comprises agricultural companies (under Eurostat activity codes 011 - Growing of non-perennial crops, and 012 - Growing of perennial crops) headquartered in Vojvodina, active in the period between 2013 and 2016. The sample comprises only stock companies and limited liability companies as the two most frequent legal forms in agriculture, forestry, and fishing sectors of Serbia (as of December 31 ${ }^{\text {st }}, 2016$, Statistical Office of the RS, 2017, p. 213). In addition, micro-sized agricultural companies, ${ }^{1}$ according to Accounting Law (The Official Gazette of the RS, 30/2018), are not included in the sample.

Companies without audited 2016 statutory financial statements, as well as companies with adverse audit opinion or disclaimers of audit opinion, are not considered in order to ensure reliability of financial data. Finally, only companies with a pre-tax profit in minimum of two years between 2013 and 2016 are sampled in order to avoid negative ETRs as much as possible.

1 Micro-sized companies are dominant in the agriculture, forestry, and fishing sectors of Vojvodina (Statistical Office of the Republic of Serbia, 2017). However, financial statements of these companies are rarely audited, and often contain only basic data from balance sheet and income statement, without any additional data (for example, from cash flow statements) 
There are 50 companies found to meet the mentioned criteria. The sample initially comprises 200 observations (50 companies across four years). However, four observations were withdrawn due to over-indebtedness, i.e., losses that exceed the owners' equity (in order to calculate ROE, and to avoid abnormal debt ratios), while eight observations were withdrawn due to pre-tax losses in order to avoid negative ETRs. Therefore, the final sample comprises 188 observations which is, according to Tabachnick and Fidell (2007, p. 123), an appropriate sample size. ${ }^{2}$ Table 1 presents the structure of sampled companies. The list of sampled companies is given in Appendix 1.

Table 1 - Structure of Sampled Companies

\begin{tabular}{|c|c|c|c|}
\hline \multicolumn{4}{|c|}{ Administrative district } \\
\hline Central Banat & 8 & South Banat & 9 \\
\hline North Bačka & 5 & Srem & 3 \\
\hline North Banat & 4 & West Bačka & 8 \\
\hline South Bačka & 13 & Total & 50 \\
\hline \multicolumn{4}{|c|}{ Legal form (as of December $31^{\text {st }}, 2016$ ) } \\
\hline Public stock company & 22 & Limited liability company & 26 \\
\hline Private stock company & 2 & Total & 50 \\
\hline \multicolumn{4}{|c|}{ Size (according to 2016 statutory financial statements) } \\
\hline Small & 14 & Large & 4 \\
\hline Middle & 32 & Total & 50 \\
\hline \multicolumn{4}{|c|}{ Audit opinion (from 2016 statutory financial statements) } \\
\hline Unqualified & 26 & Qualified & 4 \\
\hline Unqualified with emphasis of matter & 12 & Qualified with emphasis of matter & 8 \\
\hline Total & 50 & & \\
\hline
\end{tabular}

The ownership of sampled companies is highly concentrated. As of January $1^{\text {st }}, 2018$, one company from Belgrade is the direct majority shareholder in five companies, one company from Novi Sad is, through related-party entities, the majority shareholder in another five companies, while one company from Sombor is the direct majority shareholder in four additional sampled companies. Furthermore, only 11 companies have 2016 statutory financial statements audited by Big Four companies.

In this research, there is examined influence of corporate income tax on the profitability of agricultural companies. Current ETR (CuETR) and cash ETR (CaETR) are used as corporate income tax burden proxies, and ROA, ROE and ROS as profitability proxies. According to Hanlon and Heitzman (2010), current ETR and cash ETR are among the most widely used corporate income tax burden proxies. Figure 1 presents the research model.

Figure 1 - Research Model

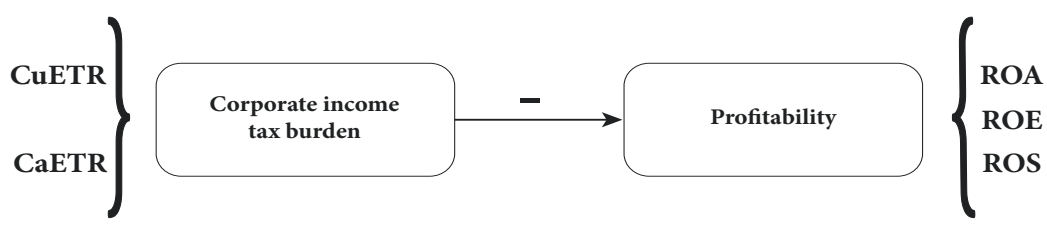

2 Tabachnick and Fidell (2007, p. 123) suggest a minimum number of observations to be calculated as follows: $N>50+8 m$, whereas $N$ refers to the minimum number of observations and $m$ refers to the number of independent variables. Since there are nine independent variables employed in the research model, the minimum sample size is 122 observations. 
Following the conclusion of Vučković (2016) about the influence of financial structure, asset structure, activity ratios, and liquidity on the profitability of agricultural companies, the following control variables are used: debt ratio (DEBTR), share of fixed assets in total assets (FIXED), asset turnover ratio (ATR) and liquidity ratio (LIQ). In accordance with Assidi et al. (2016), company size (SIZE) is used as control variable. Following Gatsi et al. (2013), the age of the company (AGE) is used as a control variable. In accordance with Vržina (2018), gross domestic product growth rate (GDP) and inflation rate measured by consumer prices index (INFL) are used as macroeconomic control variables. Table 2 presents the definition of the employed variables.

Table 2 - Definition of Variables

\begin{tabular}{|c|c|}
\hline Variable & Definition \\
\hline \multicolumn{2}{|c|}{ Dependent variables } \\
\hline $\mathrm{ROA}(\%)$ & (Net profit / Total assets) x 100 \\
\hline $\mathrm{ROE}(\%)$ & (Net profit / Equity) x 100 \\
\hline ROS (\%) & (Net profit / Sales revenue) x 100 \\
\hline \multicolumn{2}{|c|}{ Independent variables - ETRs } \\
\hline $\operatorname{CuETR}(\%)$ & (Current corporate income tax expense / Pre-tax profit) x 100 \\
\hline $\operatorname{CaETR}(\%)$ & (Corporate income tax paid / Pre-tax profit) $x 100$ \\
\hline \multicolumn{2}{|c|}{ Independent variables - firm-specific control variables } \\
\hline SIZE & Natural logarithm of total assets (in 000 Serbian dinars) \\
\hline DEBTR & Total liabilities (including deferred tax liabilities) / Total assets \\
\hline FIXED & Fixed assets / Total assets \\
\hline ATR & Sales revenue / Total assets \\
\hline LIQ & Current assets / Short-term liabilities \\
\hline AGE & $\begin{array}{l}\text { Natural logarithm of age of the company in years; age of the company is calculated as } \\
\text { the difference between balance date and incorporation date, retrieved from The Serbian } \\
\text { Business Registers Agency (2018) }\end{array}$ \\
\hline \multicolumn{2}{|c|}{ Independent variables - macroeconomic control variables } \\
\hline GDP $(\%)$ & As reported by the World Bank (2019) \\
\hline INFL (\%) & As reported by the World Bank (2019) \\
\hline
\end{tabular}

The impact of corporate income tax on company profitability is examined on the basis of regression analysis. This method has been widely used in the similar previous research (Gatsi et al., 2013; Ezugwu, \& Akubo, 2014; Al-Jafari, \& Al Samman, 2015; Assidi et al., 2016; Pitulice et al., 2016; Vržina, 2018). ${ }^{3}$ In this regard, it is possible to formulate the following general panel regression research model:

$$
\begin{gathered}
P R O F_{i t}=\alpha+\beta_{1} E T R_{i t}+\beta_{2} \operatorname{SIZE}_{i t}+\beta_{3} D E B T R_{i t}+\beta_{4} F I X E D_{i t}+\beta_{5} A T R_{i t}+\beta_{6} L I Q_{i t}+\beta_{f} A G E_{i t}+ \\
\beta_{8} G D P_{t}+\beta_{9} I N F L_{t}+\varepsilon_{i t}
\end{gathered}
$$

where PROF stands for ROA, ROE, and ROS, while ETR stands for CuETR and CaETR.

3 Most of the previous research (e.g. Gatsi et al., 2013; Al-Jafari, \& Al Samman, 2015; Vržina, 2018) used OLS regression. One exception is the research of Assidi et al. (2016) that used fixed-effects panel regression. 
Statistical data processing has been conducted in econometric software EViews, version 9, while statistical significance of results has been estimated at $10 \%, 5 \%$, and $1 \%$ confidence level. The necessary financial data has been retrieved from statutory financial statements published on the website of The Serbian Business Registers Agency (2019). ${ }^{4}$

\section{RESEARCH RESULTS}

\section{Descriptive Statistics}

The presentation of research results begins with descriptive statistics. Table 3 presents descriptive statistics for all variables used in this analysis.

Table 3 - Descriptive Statistics

\begin{tabular}{|c|c|c|c|c|c|c|}
\hline Variable & Mean & Minimum & Median & Maximum & $\begin{array}{l}\text { Standard } \\
\text { deviation }\end{array}$ & $\begin{array}{l}\text { Coefficient } \\
\text { of variation }\end{array}$ \\
\hline \multicolumn{7}{|c|}{ Dependent variables } \\
\hline $\mathrm{ROA}$ & $5.043 \%$ & $0.060 \%$ & $3.686 \%$ & $25.632 \%$ & $4.750 \%$ & 0.942 \\
\hline $\mathrm{ROE}$ & $9.035 \%$ & $0.088 \%$ & $6.986 \%$ & $91.341 \%$ & $10.126 \%$ & 1.121 \\
\hline ROS & $10.546 \%$ & $0.121 \%$ & $6.015 \%$ & $70.712 \%$ & $11.581 \%$ & 1.098 \\
\hline \multicolumn{7}{|c|}{ Independent variables - ETRs } \\
\hline CuETR & $3.561 \%$ & $0.000 \%$ & $0.000 \%$ & $42.037 \%$ & $7.391 \%$ & 2.076 \\
\hline CaETR & $4.163 \%$ & $0.000 \%$ & $0.000 \%$ & $108.632 \%$ & $12.435 \%$ & 2.987 \\
\hline \multicolumn{7}{|c|}{ Independent variables - firm-specific control variables } \\
\hline SIZE & 14.109 & 12.176 & 13.983 & 16.467 & 0.856 & 0.061 \\
\hline DEBTR & 0.372 & 0.006 & 0.385 & 0.979 & 0.255 & 0.687 \\
\hline FIXED & 0.550 & 0.127 & 0.533 & 0.938 & 0.169 & 0.308 \\
\hline ATR & 0.655 & 0.105 & 0.516 & 2.252 & 0.438 & 0.669 \\
\hline LIQ & 5.238 & 0.099 & 1.733 & 85.137 & 11.594 & 2.213 \\
\hline AGE & 2.991 & 1.109 & 3.117 & 4.261 & 0.518 & 0.173 \\
\hline \multicolumn{7}{|c|}{ Independent variables - macroeconomic control variables } \\
\hline Year & 2013 & & 2014 & 2015 & & 2016 \\
\hline GDP & \multicolumn{2}{|c|}{$2.572 \%$} & $-1.831 \%$ & \multicolumn{2}{|c|}{$0.758 \%$} & $2.797 \%$ \\
\hline INFL & \multicolumn{2}{|r|}{$7.694 \%$} & $2.082 \%$ & \multicolumn{2}{|c|}{$1.392 \%$} & $1.122 \%$ \\
\hline
\end{tabular}

Mean profitability values are considerably higher than median ones due to high maximum values. However, many observations were able to record only modest profitability rates: 39 observations have ROA between $0 \%$ and $1 \%, 17$ observations have ROE between $0 \%$ and $1 \%$, while 23 observations have ROS between $0 \%$ and 1\%. Vučković, Veselinović, and Drobnjaković (2016) argue that modest profitability of agricultural companies is primarily the consequence of high input prices and expensive bank loans.

ETR in mean and median agriculture company is well below STR of 15\%. Furthermore, 139 (139) observations have current (cash) ETR of 0\%, while only 22 (13) observations have current (cash) ETR higher than $15 \%$. It is interesting to point out that 129 observations (68.62\%) have both current ETR and cash ETR of $0 \%$. In addition, 23 (20) sampled companies had current (cash) ETR of 0\% continuously between 2013 and 2016 despite recording pre-tax profit in every observed year.

4 Raw data used in empirical analysis is available at: https://data.mendeley.com/datasets/47f9wr2r7k/2. 
There can be many explanations for the relatively low ETRs in agricultural companies. Companies may carry forward tax losses incurred until December $31^{\text {st }}, 2009$ to the following ten years and tax losses incurred after January $1^{\text {st }}, 2010$ to the following five years, to offset the taxable profit in the following years. There is also an investment tax incentive, as a company that invests at least one billion Serbian dinars in fixed assets and employs at least a hundred new workers can reduce corporate income tax liabilities over the following ten years. It is interesting to point out that 22 of sampled 50 companies have continuously increased the value of fixed assets between 2013 and 2016, which can be an indicator of significant investment in fixed assets.

Highly concentrated ownership of sampled agricultural companies enables a reduction of corporate income tax liabilities through related-party transactions and transfer pricing system. Furthermore, related companies can benefit from tax consolidation. If one company owns more than $75 \%$ of one or more companies, it can apply for tax consolidation and offset profits of one company with losses of another related company. Related companies can, in this way, minimize the corporate income tax liabilities that are allocated on individual companies according to the share of their profits in consolidated profit.

Agricultural companies have a relatively low debt ratio since their share of debt in total assets in mean and median company is lower than 50\%. This is in line with the conclusion of Popović, Janković, and Stojanović (2018) about agricultural loans as an unutilized bank credit market segment in Serbia which can be serious deficient as it that slows down the development of agricultural companies. On the other hand, the share of fixed assets in total assets in mean and median agricultural company is higher than $50 \%$.

The asset turnover ratio is higher than one in only 31 observations. In the context of liquidity ratio, a very low minimum and very high maximum value, as well as high mean value, indicate that many agricultural companies have problem with disparity between assets maturity and debt maturity, as pointed out by Jakšić, Vuković, and Mijić (2011).

The statistical significance of the difference between current (cash) ETR and STR is tested in order to examine the validity of the first research hypothesis. Since current ETR and cash ETR are not normally distributed, median tests of equality of samples (Wilcoxon/Mann-Whitney tie-adjusted method) have been conducted, and their results are presented in the Table 4.

Table 4 - Tests of Equality Between Current (Cash) Effective Corporate Income Tax Rate (ETR) and Statutory Corporate Income Tax Rate (STR)

\begin{tabular}{cccr}
\hline Tax rate 1 & Tax rate 2 & Test Value & \multicolumn{2}{c}{ p-value } \\
\hline Current ETR & STR & 14.146 & ${ }^{* * *} 0.000$ \\
\hline Cash ETR & STR & 15.915 & ${ }^{* * *} 0.000$ \\
\hline
\end{tabular}

Note: Statistically significant at $10 \%(*), 5 \%(* *)$, and $1 \%(* * *)$ confidence level.

The results of statistical tests indicate that statistically significant difference exists between current (cash) ETR and STR. These results are quite understandable, since median values of current and cash ETRs are $0 \%$. On the other hand, there is no significant difference between current ETR and cash ETR (test value $=0.189 ; \mathrm{p}$-value $=0.850$ ). Therefore, the first research hypothesis cannot be rejected . 


\section{Univariate Analysis}

Table 5 presents Pearson's correlation coefficients and their statistical significance. There is significant correlation between profitability proxies: ROA and ROE as well as ROA and ROS are highly positively correlated, while ROE and ROS are moderately positively correlated. Current ETR is significantly negatively correlated with all three profitability proxies, while cash ETR is significantly negatively correlated with ROA and ROS.

Among the independent variables, the highest correlation appears between debt ratio and asset turnover ratio. On the other hand, gross domestic product is the only variable that is not significantly correlated to any other variable from research model.

Table 5 - Pearson's Correlation Matrix

\begin{tabular}{|c|c|c|c|c|c|c|c|}
\hline Variable & ROA & ROE & ROS & CuETR & CaETR & SIZE & DEBTR \\
\hline ROA & 1 & & & & & & \\
\hline $\mathrm{ROE}$ & ${ }^{* * *} 0.636$ & 1 & & & & & \\
\hline ROS & ${ }^{* * *} 0.715$ & ${ }^{* * *} 0.300$ & 1 & & & & \\
\hline CuETR & ${ }^{* * *}-0.241$ & ${ }^{*}-0.126$ & $* * *-0.196$ & 1 & & & \\
\hline CaETR & $* * *-0.213$ & -0.115 & ${ }^{* *}-0.178$ & ${ }^{* * *} 0.522$ & 1 & & \\
\hline SIZE & 0.087 & -0.082 & ${ }^{* * *} 0.308$ & ${ }^{*}-0.142$ & ${ }^{* *}-0.144$ & 1 & \\
\hline DEBTR & $* * *-0.336$ & ${ }^{* * *} 0.247$ & $* * *-0.470$ & ${ }^{* * *} 0.210$ & ${ }^{* *} 0.144$ & *-0.129 & 1 \\
\hline FIXED & $*-0.126$ & ${ }^{* *}-0.186$ & 0.049 & $* * *-0.253$ & $* * *-0.207$ & ${ }^{* * *} 0.224$ & $* * *-0.214$ \\
\hline ATR & ${ }^{\star} 0.135$ & ${ }^{* * *} 0.487$ & $* * *-0.370$ & 0.096 & 0.056 & $* * *-0.362$ & ${ }^{* * *} 0.518$ \\
\hline LIQ & ${ }^{* *} 0.175$ & -0.048 & ${ }^{* * *} 0.348$ & -0.106 & -0.070 & 0.081 & $* * *-0.453$ \\
\hline AGE & $*-0.133$ & $* * *-0.265$ & -0.111 & -0.057 & -0.086 & -0.117 & $* *-0.172$ \\
\hline GDP & 0.029 & 0.031 & 0.039 & -0.052 & 0.039 & 0.004 & 0.005 \\
\hline INFL & ${ }^{* * *} 0.200$ & ${ }^{\star *} 0.179$ & 0.047 & -0.116 & ${ }^{* *}-0.152$ & -0.106 & -0.004 \\
\hline Variable & FIXED & ATR & LIQ & AGE & GDP & INFL & \\
\hline \multicolumn{8}{|l|}{ ROA } \\
\hline \multicolumn{8}{|l|}{$\mathrm{ROE}$} \\
\hline \multicolumn{8}{|l|}{ ROS } \\
\hline \multicolumn{8}{|l|}{ CuETR } \\
\hline \multicolumn{8}{|l|}{ CaETR } \\
\hline \multicolumn{8}{|l|}{ SIZE } \\
\hline \multicolumn{8}{|l|}{ DEBTR } \\
\hline FIXED & 1 & & & & & & \\
\hline ATR & $* * *-0.383$ & 1 & & & & & \\
\hline LIQ & -0.051 & $* * *-0.228$ & 1 & & & & \\
\hline AGE & 0.056 & ${ }^{*}-0.152$ & 0.069 & 1 & & & \\
\hline GDP & 0.024 & 0.005 & 0.047 & 0.015 & 1 & & \\
\hline INFL & 0.035 & 0.092 & -0.044 & $*-0.121$ & ${ }^{* * *} 0.332$ & 1 & \\
\hline
\end{tabular}

Note: Statistically significant at $10 \%(*), 5 \%\left({ }^{* *}\right)$, and $1 \%\left({ }^{* *}\right)$ confidence level. 


\section{Regression Analysis}

Since the influence of two corporate income tax burden proxies (CuETR and CaETR) on three profitability proxies (ROA, ROE and ROS) has been studied, there are six regression models to be reported. Regarding multicollinearity statistics, Variance Inflation Factor and Tolerance statistics are considerably lower than 10 and higher than 0.10 , respectively, for each independent variable in all six regression models, so problems with multicollinearity are not expected. Relying on Ratner (2009) correlation criteria, it can be concluded there is no high correlation between independent variables, confirming the absence of multicollinearity.

Table 6 presents the results of the Breusch-Pagan LM test and Hausman test, used to determine which regression method is the most appropriate. According to Breusch-Pagan LM tests, random-effects regression outperform Ordinary Least Squares (OLS) regression in each regression model. Hausman tests indicate that the random-effects regression is more appropriate in the first four models, while fixed-effects regression should be employed in the last two models.

Table 6 - Results of Statistical Tests

\begin{tabular}{|c|c|c|c|c|c|c|c|}
\hline & & \multirow{2}{*}{\multicolumn{2}{|c|}{$\begin{array}{l}\text { Dependent: ROA } \\
\text { Corporate income } \\
\text { tax burden proxy: }\end{array}$}} & \multirow{2}{*}{\multicolumn{2}{|c|}{$\begin{array}{l}\text { Dependent: ROE } \\
\text { Corporate income } \\
\text { tax burden proxy: }\end{array}$}} & \multirow{2}{*}{\multicolumn{2}{|c|}{$\begin{array}{l}\text { Dependent: ROS } \\
\text { Corporate income } \\
\text { tax burden proxy: }\end{array}$}} \\
\hline & & & & & & & \\
\hline & & CuETR & CaETR & CuETR & CaETR & CuETR & CaETR \\
\hline \multirow{3}{*}{$\begin{array}{l}\text { Breusch- } \\
\text { Pagan LM } \\
\text { test }\end{array}$} & Cross-section & $\begin{array}{r}47.091 \\
(0.000) \\
\end{array}$ & $\begin{array}{r}45.848 \\
(0.000 \\
\end{array}$ & $\begin{array}{r}67.913 \\
(0.000) \\
\end{array}$ & $\begin{array}{r}64.831 \\
(0.000) \\
\end{array}$ & $\begin{array}{r}57.471 \\
(0.000) \\
\end{array}$ & $\begin{array}{r}55.572 \\
(0.000) \\
\end{array}$ \\
\hline & Test Hypothesis Time & $\begin{array}{r}0.549 \\
(0.459)\end{array}$ & $\begin{array}{r}0.716 \\
(0.398)\end{array}$ & $\begin{array}{r}1.073 \\
(0.300)\end{array}$ & $\begin{array}{r}1.269 \\
(0.260)\end{array}$ & $\begin{array}{r}1.491 \\
(0.222)\end{array}$ & $\begin{array}{r}1.573 \\
(0.210)\end{array}$ \\
\hline & Both & $\begin{array}{r}47.640 \\
(0.000)\end{array}$ & $\begin{array}{r}46.564 \\
(0.000)\end{array}$ & $\begin{array}{r}68.987 \\
(0.000)\end{array}$ & $\begin{array}{r}66.100 \\
(0.000)\end{array}$ & $\begin{array}{r}58.962 \\
(0.000)\end{array}$ & $\begin{array}{l}57.145 \\
(0.000)\end{array}$ \\
\hline \multirow{3}{*}{$\begin{array}{c}\text { Hausman } \\
\text { test }\end{array}$} & Chi-Sq. Statistic & 14.069 & 13.623 & 11.829 & 12.300 & 22.763 & 20.911 \\
\hline & Chi-Sq. d.f. & 9 & 9 & 9 & 9 & 9 & 9 \\
\hline & $\mathrm{p}$-value & 0.120 & 0.136 & 0.223 & 0.197 & 0.007 & 0.013 \\
\hline
\end{tabular}

Note: $p$-values in parentheses. 
Table 7 - Panel Regression Estimates

\begin{tabular}{|c|c|c|c|c|c|c|}
\hline \multirow{2}{*}{$\begin{array}{c}\text { Variable } \\
\text { Effects }\end{array}$} & \multicolumn{2}{|c|}{ Dependent: ROA } & \multicolumn{2}{|c|}{ Dependent: ROE } & \multicolumn{2}{|c|}{ Dependent: ROS } \\
\hline & Random & Random & Random & Random & Fixed & Fixed \\
\hline \multirow{2}{*}{ Intercept } & -2.160 & -2.136 & 20.303 & 19.711 & $* *-130.770$ & *-111.316 \\
\hline & $(-0.243)$ & $(-0.240)$ & $(0.971)$ & $(0.938)$ & $(-2.053)$ & $(-1.743)$ \\
\hline \multirow{2}{*}{ CuETR } & $* *-0.092$ & & $* * *-0.244$ & & ${ }^{* *}-0.240$ & \\
\hline & $(-2.420)$ & & $(-3.063)$ & & $(-2.461)$ & \\
\hline \multirow{2}{*}{ CaETR } & & ${ }^{*}-0.036$ & & ${ }^{*}-0.084$ & & ${ }^{*}-0.091$ \\
\hline & & $(-1.685)$ & & $(-1.899)$ & & $(-1.770)$ \\
\hline \multirow{2}{*}{ SIZE } & ${ }^{\star} 0.926$ & ${ }^{\star} 0.924$ & -0.560 & -0.529 & 2.834 & 2.112 \\
\hline & $(1.722)$ & $(1.719)$ & $(-0.442)$ & $(-0.416)$ & $(0.739)$ & $(0.546)$ \\
\hline \multirow{2}{*}{ DEBTR } & $* * *-11.235$ & $* * *-11.253$ & -1.465 & -1.415 & ${ }^{* *}-19.424$ & ${ }^{* *}-18.208$ \\
\hline & $(-6.388)$ & $(-6.374)$ & $(-0.373)$ & $(-0.357)$ & $(-2.591)$ & $(-2.405)$ \\
\hline \multirow{2}{*}{ FIXED } & $* *-5.069$ & ${ }^{* *}-4.793$ & 1.565 & 2.203 & -13.194 & -13.022 \\
\hline & $(-2.129)$ & $(-2.008)$ & $(0.295)$ & $(0.411)$ & $(-1.552)$ & $(-1.512)$ \\
\hline \multirow{2}{*}{ ATR } & $* * * 5.133$ & $* * * 4.968$ & $* * * 11.552$ & $* * * 11.105$ & -2.100 & -3.689 \\
\hline & $(4.790)$ & $(4.585)$ & $(4.812)$ & $(4.548)$ & $(-0.457)$ & $(-0.786)$ \\
\hline \multirow{2}{*}{ LIQ } & -0.009 & -0.010 & 0.027 & 0.024 & -0.011 & -0.023 \\
\hline & $(-0.288)$ & $(-0.318)$ & $(0.433)$ & $(0.380)$ & $(-0.138)$ & $(-0.284)$ \\
\hline \multirow{2}{*}{ AGE } & -0.868 & -0.944 & ${ }^{\star}-3.823$ & *-3.995 & $\star * * 38.523$ & $* * * 35.504$ \\
\hline & $(-1.003)$ & $(-1.093)$ & $(-1.849)$ & $(-1.932)$ & $(3.742)$ & $(3.454)$ \\
\hline \multirow{2}{*}{ GDP } & -0.071 & -0.042 & -0.048 & 0.020 & ${ }^{*}-0.612$ & -0.478 \\
\hline & $(-0.591)$ & $(-0.340)$ & $(-0.195)$ & $(0.081)$ & $(-1.846)$ & $(-1.434)$ \\
\hline \multirow[b]{2}{*}{ INFL } & ${ }^{* * *} 0.257$ & ${ }^{* * *} 0.254$ & ${ }^{\star} 0.324$ & ${ }^{\star} 0.327$ & $* * * 1.165$ & $* * * 1.071$ \\
\hline & $(2.790)$ & $(2.691)$ & $(1.688)$ & $(1.660)$ & $(3.371)$ & $(3.071)$ \\
\hline Adj. $\mathrm{R}^{2}$ & 0.275 & 0.264 & 0.224 & 0.201 & 0.690 & 0.683 \\
\hline F-Value & $* * * 8.866$ & $* * * 8.449$ & $* * * 7.010$ & $* * * 6.234$ & $* * * 8.300$ & $* * * 8.073$ \\
\hline
\end{tabular}

Note: Beta coefficients in front of the parentheses, $t$-statistics in the parentheses; statistically significant at $10 \%$ $(*), 5 \%(* *)$ ) and $1 \%(* * *)$ confidence level.

Panel regression estimates are reported in Table $7,{ }^{5}$ showing that the reduction of ETRs increases the profitability of agricultural companies in Vojvodina, though this impact is relatively weak. In this context, has current ETR has the strongest impact on ROE, whereas a reduction in the current ETR of $1 \%$ increases ROE for only $0.244 \%$. Furthermore, the impact of the current ETR on profitability is stronger than the impact of cash ETR.

The weak influence of corporate income tax burden on the profitability of agricultural companies should not be surprising given that most of the observations have ETRs considerably lower than STR. Current ETR and cash ETR, as well as the inflation rate, are the only independent variables that significantly influence every profitability proxy, so results are robust to corporate income tax burden and profitability proxies changes.

There are many reasons that can explain why agricultural companies with lower ETRs have a higher profitability. Firstly, several agricultural companies that overcame difficulties during the global crisis (in 2008 and 2009) became more profitable. On the other hand, these companies use tax loss carryforward to reduce ETRs.

5 OLS regression estimates and other regressions estimates are given in Appendix 2 and Appendix 3, respectively. 
Tax losses from 2008 and 2009 can be carried forward into the following ten years. Secondly, it is possible that high profitability of agricultural companies is a consequence of the high efficiency of investment in fixed assets. On the other hand, these companies use investment tax incentive to reduce ETRs. Therefore, the second research hypothesis cannot be rejected.

Larger companies have significantly higher ROA. Debt ratio significantly influences ROA and ROS - due to the existence of interest expenses, companies with higher debt ratio have lower ROA and ROS. Companies with a higher share of fixed assets in total assets, due to fixed depreciation and amortization costs, have lower ROA. Companies with a higher asset turnover ratio have higher ROA and ROE.

Older agricultural companies have significantly lower ROE, yet higher ROS. Liquidity and the gross domestic product growth rate are independent variables that are not a significant determinant of profitability in any regression model. Finally, the inflation rate significantly influences each profitability proxy - agricultural companies had higher ROA, ROE and ROS in years with higher inflation rates.

\section{CONCLUSION}

This paper analyzed the determinants of profitability of 50 agricultural companies in Vojvodina in the period between 2013 and 2016, with a focus on the impact of corporate income tax on company profitability. Corporate income tax burden has been proxied with current ETR and cash ETR, while profitability has been proxied with ROA, ROE and ROS.

Statistical analysis showed that ETRs in agricultural companies are significantly lower than STR of $15 \%$. In addition, nearly $69 \%$ of observations have both current ETR and cash ETR of $0 \%$. Reasons for relatively low ETRs can be found in tax loss carryforward and investment tax incentive permitted by law, as well as transfer pricing and tax consolidation opportunities, since ownership of the sampled companies is highly concentrated. These results indicate that agriculture is an industry with exceptionally low corporate income tax burden. Findings about ETR lower than STR are consistent with Al-Jafari and Al Samman (2015) and Assidi et al. (2016), though statistical significance of the difference between ETR and STR has not been tested in these papers.

It was found that a reduction of ETRs leads to a significant increase of profitability of agricultural companies when analyzing panel regression. These results indicate that companies that use tax loss carryforward have recovered from losses, and that companies that use investment tax incentive have high efficiency of their investments. However, this impact is relatively weak, due to the low corporate income tax burden of agricultural companies. This finding is in line with Gatsi et al. (2013), Assidi et al. (2016), and Pitulice et al. (2016).

Considering the obtained research results, neither research hypotheses can be rejected. Research results are not sensitive to change of corporate income tax burden or profitability proxies. Managers of agricultural companies can benefit from the research, which recognizes the important variables of their companies' success. Managers should particularly realize that relying on minimizing ETRs is a significant cost-efficient strategy leading to increase of management efficiency.

However, users of these results should bear in mind that a possible limitation of the research results lies in the fact that the analysis covered only 50 agricultural companies. It is possible that research results would be different had the sample size and/or sampling period been different. Furthermore, removing some observations (with pre-tax loss, with losses that exceed owners' equity or with adverse audit opinion or disclaimer of audit opinion) could impact research results. Henry and Sansing (2018) 
argue that removing pre-tax loss observations could be a particularly important limitation. Since many sampled companies had qualified audit opinions, which could indicate meaningful misstatements in financial statements, research results should be interpreted carefully.

The presented results emphasize the importance of corporate income tax in microeconomic analysis and the need for further inclusion of tax aspects in the analysis of company financial performance. Research results additionally indicate that agricultural companies should continue to minimize their corporate income tax burden in order to be more profitable. Future research should include the period before 2013, during which STR was 10\%, and compare the obtained results in the period before and after the increase of STR. Moreover, future research should compare the corporate income tax burden of agricultural companies with the burden of companies from other industries. It would be also interesting to research the determinants of ETRs in agricultural companies assuming, that bigger and more profitable companies might have more power and resources to lower the tax burden.

\section{ACKNOWLEDGEMENT}

This paper is a part of the Project III 47005, financed by the Ministry of Education, Science and Technological Development of the Republic of Serbia.

\section{REFERENCES}

Accounting Law, The Official Gazette of the RS, no. 30/2018.

Al-Jafari, M., \& Al Samman, H. (2015). Determinants of Profitability: Evidence from Industrial Companies Listed on Muscat Securities Market. Review of European Studies, 7(11), 303-311. DOI: 10.5539/res.v7n11p303.

Andreoni, J., Erard, B., \& Feinstein, J. (1998). Tax Compliance. Journal of Economic Literature, 36(2), 818-860. DOI: 10.1007/978-3-8349-8282-7_12.

Assidi, S., Aliani, K., \& Omri, M. (2016). Tax Optimization and the Firm's Value: Evidence from the Tunisian Context. Borsa Istanbul Review, 16(3), 177-184. DOI: 10.1016/j.bir.2016.04.002.

Atanasijević, J., \& Danon, M. (2014). Financing Agricultural Development in Serbia: Opportunities and Challenges. Ekonomika preduzeća, 62(1-2), 67-81. DOI: 10.5937/ekopre1402067A.

Birovljev, J., Đokić, D., Matkovski, B., \& Kleut, Ž. (2017). Economics Performances of Agriculture of CEFTA and Former CEFTA Countries. Economics of Agriculture, 64(4), 1413-1424. DOI: doi:10.5937/ekoPolj1704413B.

Bubić, J., \& Hajnrih, J. (2012). The Analyses Business Performances of Agricultural Enterprises in Vojvodina During the Current Crisis. Economics of Agriculture, 59(2), 183-194.

Chrastinova, Z., \& Burianova, V. (2009). Economic Development in Slovak Agriculture. Agricultural Economics, 55(2), 67-76. DOI: 10.17221/580-agricecon.

Corporate Profit Tax Law, The Official Gazette of the RS, no. 113/2017.

Crocker, K., \& Slemrod, J. (2005). Corporate Tax Evasion with Agency Costs. Journal of Public Economics, 89(1), 1593-1610. DOI: 10.1016/j.jpubeco.2004.08.003.

Dhaliwal, D., Gleason, C., \& Mills, L. (2004). Last-Chance Earnings Management: Using the Tax Expense to Meet Analysts' Forecasts. Contemporary Accounting Research, 21(2), 431-459. DOI: 10.1506/tfvv-uyt1-nnyt-1yfh.

Đuričin, S., \& Bodroža, D. (2013). The Impact of Drought on Yield Position of the Group of Enterprises from Agriculture Sector. Economics of Agriculture, 60(1), 25-38.

Ezugwu, C., \& Akubo, D. (2014). Analysis of the Effect of High Corporate Tax Rate on the Profitability of Corporate Organizations in Nigeria - A Study of Some Selected Corporate Organizations. Mediterranean Journal of Social Sciences, 5(20), 310-321. DOI: 10.5901/mjss.2014.v5n20p310. 
Gatsi, J., Gadzo, S., \& Kportorgbi, H. (2013). The Effect of Corporate Income Tax on Financial Performance of Listed Manufacturing Firms in Ghana. Research Journal of Finance and Accounting, 4(15), 118-124.

Hanlon, M., \& Heitzman, S. (2010). A Review of Tax Research. Journal of Accounting and Economics, 50(2-3), 127-178. DOI: 10.1016/j.jacceco.2010.09.002.

Henry, E., \& Sansing, R. (2018). Corporate Tax Avoidance: Data Truncation and Loss Firms. Review of Accounting Studies, 23(3), 1042-1070. DOI: 10.1007/s11142-018-9448-0.

Hogsden, J. (2018). The Contemporary Corporate Tax Strategy Environment. In E. Conway \& D. Byrne (Ed.) Contemporary Issues in Accounting (pp. 85-104). Cham, Switzerland: Palgrave Macmillan.

Jakšić, D., Vuković, B., \& Mijić, K. (2011). Analiza finansijskog položaja poljoprivrednih preduzeća u Republici Srbiji. Ekonomika poljoprivrede, 58(1), 81-90. In Serbian.

Jakšić, D., Zekić, S., Ristić, M., \& Mijić, K. (2016). Profitabilnost poljoprivrednih preduzeća u zemljama Jugoistočne Evrope. Agroekonomika, 45(71), 1-11. In Serbian.

Kocsis, J., \& Major, K. (2017). A General Overview of Agriculture and Profitability in Agricultural Enterprises in Central Europe. In P. Bryla (Ed.) Managing Agricultural Enterprises (pp. 243-265). Cham, Switzerland: Palgrave Macmillan.

Mijić, K., \& Jakšić, D. (2016). Sektorska analiza profitabilnosti privrede Srbije. Ekonomski pogledi, 18(2), 1-12. In Serbian.

Miklos, S. (2014). Hungarian Agriculture a Decade after EU Accession: Hopes, Facts and Lessons. Unia Europejska, 225(2), 41-51.

Mitrović, S., Mitrović, A., \& Cogoljević, M. (2017). Contribution of Agriculture to the Development of Serbia. Economics of Agriculture, 64(2), 805-819. DOI: 10.5937/ekopolj1702805m.

Pitulice, I., Stefanescu, A., Minzu, V., Popa, A., \& Niculescu, A. (2016). Research of Corporate Tax Impact on Financial Performance. Case of Companies Listed on Bucharest Stock Exchange. Management and Economics Review, 1(2), 203-216.

Popović, S., Janković, I., \& Stojanović, Ž. (2018). The Importance of Bank Credits for Agricultural Financing in Serbia. Economics of Agriculture, 65(1), 65-80. DOI: 10.5937/ekopolj1801065p.

Prinz, A., Muehlbacher, S., \& Kirchler, E. (2014). The Slippery Slope Framework on Tax Compliance: An Attempt to Formalization. Journal of Economic Psychology, 40(1), 20-34. DOI: 10.1016/j.joep.2013.04.004.

Radulović, B., \& Dragutinović, S. (2015). Case Studies of Privatizations in Serbia. Belgrade, Serbia: National Alliance for Local Economic Development.

Ratner, B. (2009). The Correlation Coefficient: Its Value Range between $+1 /-1$, or Do They? Journal of Targeting, Measurement and Analysis for Marketing, 17(2), 139-142. DOI: 10.1057/jt.2009.5.

Republički zavod za statistiku RS (2017). Preduzeća u Republici Srbiji, prema veličini, 2016. Retrieved January 1, 2019, from http://pod2.stat.gov.rs/objavljenepublikacije/g2017/pdf/g201710099.pdf. In Serbian.

Stanojević, J., Krstić, B., \& Đekić, S. (2015). An Analysis of the Labour Productivity of the Agricultural Sector in the Republic of Serbia. Economic Themes, 53(4), 467-482. DOI: 10.1515/ethemes-2015-0027.

Statistical Office of the RS (2017). Statistical Yearbook. Retrieved January 1, 2019, from http://publikacije.stat. gov.rs/g2017/pdf/g20172022.pdf

Tabachnick, B., \& Fidell, L. (2007). Using Multivariate Statistics, $5^{\text {th }}$ edition. Boston, MA: Pearson Education.

The Serbian Business Registers Agency (2019). Business Entities - Search. Retrieved January 1, 2019, from http:// www.apr.gov.rs/eng/registers/companies/search.aspx

Vučković, B. (2016). Causes of Different Profitability of Agricultural Sector. Economics of Agriculture, 63(1), 123-141. DOI: 10.5937/ekopolj1601123v.

Vržina, S. (2018). Corporate Income Tax Planning and Financial Performance: Evidence from Serbia. In V. Babić (Ed.) Contemporary Issues in Economics, Business and Management (pp. 463-472). Kragujevac, Serbia: Faculty of Economics. 
Vučković, B., Veselinović, B. \& Drobnjaković, M. (2016). Analysis of Profitability of Selected Agricultural Enterprises in the Autonomous Province of Vojvodina, Republic of Serbia. Actual Problems of Economics, 176(2), 147-159.

Vučković, B., Veselinović, B. \& Vučković, A. (2017). Adekvatna struktura sredstava kao osnov profitabilnosti preduzeća. Anali Ekonomskog fakulteta u Subotici, 53(38), 51-68. In Serbian.

Vukoje, V., \& Dulić, V. (2017). Kretanje osnovnih indikatora uspeha poljoprivrednih preduzeća Vojvodine. Agroekonomika, 46(73), 43-53. In Serbian.

Vukoje, V., Miljatović, A., \& Zoranović, T. (2017). Ocena finansijskog položaja privrednih društava iz agrosektora Vojvodine. Agroekonomika, 46(76), 119-129. In Serbian.

Vukoje, V., \& Vukelić, G. (2010). Finansijsko propadanje poljoprivrednih preduzeća Vojvodine. Računovodstvo, 54(5-6), 94-102. In Serbian.

Vukoje, V., \& Zekić, V. (2010). Ekonomski položaj poljoprivrednih preduzeća u Vojvodini (2001-2009). Ekonomika poljoprivrede, 57(3), 411-424. In Serbian.

World Bank (2019). Serbia - Data. Retrieved January 1, 2019, from http://data.worldbank.org/country/serbia

Zekić, S., Gajić, M., \& Kresoja, M. (2012). Razvojne performanse agrarnog sektora Srbije u funkciji prevazilaženja ekonomsko-finansijske krize. Anali Ekonomskog fakulteta u Subotici, 48(27), 97-109. In Serbian. 


\section{APPENDIX 1}

List of Sampled Companies

\begin{tabular}{|c|c|c|c|c|c|}
\hline No. & $\begin{array}{c}\text { Registration } \\
\text { number }\end{array}$ & Company name & No. & $\begin{array}{c}\text { Registration } \\
\text { number }\end{array}$ & Company name \\
\hline 1 & 08750718 & Agrogrnja & 26 & 08028419 & Miletić \\
\hline 2 & 08276188 & Agrohemika & 27 & 08011079 & Napredak \\
\hline 3 & 20084740 & Agroprom Com & 28 & 08237930 & Nova Budućnost \\
\hline 4 & 08188190 & Agro-Promet & 29 & 08044376 & Nova Peščara \\
\hline 5 & 08120544 & Agros & 30 & 08047723 & Omoljica \\
\hline 6 & 08003572 & Agrounija & 31 & 08056811 & Panonija \\
\hline 7 & 08219699 & Agrovet & 32 & 20655526 & Per-Agro \\
\hline 8 & 08325316 & Almex & 33 & 08053324 & Petefi \\
\hline 9 & 08035512 & Banatski Despotovac & 34 & 08607753 & PIK Bečej \\
\hline 10 & 08246670 & Bezdan & 35 & 08154848 & PIK Južni Banat \\
\hline 11 & 08057729 & Borac & 36 & 08055157 & Pionir \\
\hline 12 & 08144532 & Budućnost & 37 & 08142599 & Pobeda \\
\hline 13 & 20698764 & Ćirić Agro MĐŽ & 38 & 08684936 & Podunavlje \\
\hline 14 & 08056757 & Doža Đerđ & 39 & 08064911 & Poljoprivredna proizvodnja \\
\hline 15 & 08065616 & Feketić & 40 & 08305480 & Potkozarje \\
\hline 16 & 08470634 & Fotos & 41 & 08069042 & Ratkovo \\
\hline 17 & 08021848 & Galad & 42 & 08049335 & Ravnica \\
\hline 18 & 08057664 & Graničar & 43 & 08065888 & Sava Kovačević \\
\hline 19 & 08057621 & Grmeč & 44 & 08021899 & Sloga \\
\hline 20 & 08121893 & Hajdučica & 45 & 08047731 & Stari Tamiš \\
\hline 21 & 08129525 & Jedinstvo Apatin & 46 & 08021856 & Topola \\
\hline 22 & 08021937 & Jedinstvo Kikinda & 47 & 08671613 & Uljarice-Bačka \\
\hline 23 & 08047715 & Kačarevo & 48 & 08043787 & Vojvodina \\
\hline 24 & 08021902 & Kozara & 49 & 20419482 & Vrebalov Agrar \\
\hline 25 & 08115842 & Maglić & 50 & 08035466 & Zlatica \\
\hline
\end{tabular}




\section{APPENDIX 2}

OLS Regression Estimates

\begin{tabular}{|c|c|c|c|c|c|c|}
\hline \multirow{3}{*}{$\begin{array}{l}\text { Variable } \\
\text { Intercept }\end{array}$} & \multicolumn{2}{|c|}{ Dependent: ROA } & \multicolumn{2}{|c|}{ Dependent: ROE } & \multicolumn{2}{|c|}{ Dependent: ROS } \\
\hline & -2.118 & -1.910 & 2.163 & 1.946 & -2.161 & -0.156 \\
\hline & $(-0.344)$ & $(-0.306)$ & $(0.160)$ & $(0.142)$ & $(-0.144)$ & $(-0.010)$ \\
\hline \multirow{2}{*}{ CuETR } & $* * *-0.112$ & & $* * *-0.238$ & & ${ }^{*}-0.166$ & \\
\hline & $(-2.725)$ & & $(-2.636)$ & & $(-1.659)$ & \\
\hline \multirow{2}{*}{ CaETR } & & $* *-0.058$ & & $* *-0.113$ & & ${ }^{*}-0.115$ \\
\hline & & $(-2.381)$ & & $(-2.092)$ & & $(-1.941)$ \\
\hline \multirow{2}{*}{ SIZE } & $* * * 0.980$ & ${ }^{* *} 0.964$ & 0.744 & 0.737 & $* * 2.643$ & $* * * 2.547$ \\
\hline & $(2.640)$ & $(2.570)$ & $(0.915)$ & $(0.895)$ & $(2.922)$ & (2.810) \\
\hline \multirow{2}{*}{ DEBTR } & $* * *-10.071$ & $* * *-10.346$ & $* * *-10.346$ & 0.974 & $* * *-15.050$ & $* * *-15.305$ \\
\hline & $(-6.882)$ & $(-7.085)$ & $(-7.085)$ & $(0.304)$ & $(-4.223)$ & $(-4.337)$ \\
\hline \multirow{2}{*}{ FIXED } & $* *-4.848$ & $* *-4.526$ & -2.789 & -1.949 & **-9.898 & $*^{*}-9.830$ \\
\hline & $(-2.531)$ & $(-2.370)$ & $(-0.664)$ & $(-0.465)$ & $(-2.122)$ & $(-2.130)$ \\
\hline \multirow{2}{*}{ ATR } & $* * 4.292$ & $* * * 4.322$ & ${ }^{* * *} 10.782$ & ${ }^{* * *} 10.894$ & $* *-4.551$ & $* *-4.628$ \\
\hline & $(4.994)$ & $(5.004)$ & (5.726) & (5.744) & $(-2.175)$ & $(-2.217)$ \\
\hline \multirow{2}{*}{ LIQ } & -0.002 & -0.001 & 0.061 & 0.063 & ${ }^{* *} 0.137$ & ${ }^{* *} 0.136$ \\
\hline & $(-0.065)$ & $(-0.039)$ & $(0.981)$ & $(1.011)$ & $(1.995)$ & $(1.992)$ \\
\hline \multirow{2}{*}{ AGE } & $* *-1.154$ & $* *-1.228$ & $* * *-3.480$ & $* * *-3.604$ & $* * *-3.848$ & $* * *-4.042$ \\
\hline & $(-2.004)$ & $(-2.110)$ & $(-2.758)$ & $(-2.821)$ & $(-2.744)$ & $(-2.874)$ \\
\hline \multirow{2}{*}{ GDP } & -0.067 & -0.021 & -0.091 & -0.001 & 0.102 & 0.193 \\
\hline & $(-0.415)$ & $(-0.127)$ & $(-0.258)$ & $(-0.004)$ & $(0.261)$ & $(0.490)$ \\
\hline \multirow{2}{*}{ INFL } & ${ }^{* *} 0.285$ & ${ }^{* *} 0.266$ & 0.424 & 0.393 & 0.236 & 0.179 \\
\hline & $(2.433)$ & $(2.226)$ & $(1.649)$ & (1.499) & $(0.826$ & $(0.622)$ \\
\hline Adj. $\mathrm{R}^{2}$ & 0.329 & 0.323 & 0.292 & 0.282 & 0.331 & 0.335 \\
\hline F-Value & ${ }^{* * *} 11.202$ & *** 10.908 & $* * * 9.556$ & $* * * 9.148$ & ${ }^{* * *} 11.282$ & ${ }^{* * *} 11.456$ \\
\hline
\end{tabular}

Note: Beta coefficients in front of the parentheses, $t$-statistics in the parentheses; statistically significant at $10 \%$ $(*), 5 \%(* *)$, and $1 \%(* *)$ confidence level. 


\section{APPENDIX 3}

Other regressions estimates

\begin{tabular}{|c|c|c|c|c|c|c|}
\hline \multirow{2}{*}{$\begin{array}{c}\text { Variable } \\
\text { Effects }\end{array}$} & \multicolumn{2}{|c|}{ Dependent: ROA } & \multicolumn{2}{|c|}{ Dependent: ROE } & \multicolumn{2}{|c|}{ Dependent: ROS } \\
\hline & Fixed & Fixed & Fixed & Fixed & Random & Random \\
\hline \multirow{2}{*}{ Intercept } & -2.987 & 5.235 & $* * 142.474$ & $* * * 162.413$ & -9.364 & -7.468 \\
\hline & $(-0.106)$ & $(0.184)$ & (2.477) & (2.792) & $(-0.421)$ & $(-0.337)$ \\
\hline \multirow{2}{*}{ CuETR } & $*^{*}-0.101$ & & $* * *-0.244$ & & ${ }^{*}-0.160$ & \\
\hline & $(-2.331)$ & & $(-2.780)$ & & $(-1.830)$ & \\
\hline \multirow{2}{*}{ CaETR } & & -0.026 & & -0.073 & & ${ }^{*}-0.082$ \\
\hline & & $(-1.160)$ & & $(-1.567)$ & & $(-1.696)$ \\
\hline \multirow{2}{*}{ SIZE } & -0.982 & -1.268 & $* * *-9.625$ & $* * *-10.335$ & $* * *-17.826$ & $* * *-17.646$ \\
\hline & $(-0.578)$ & $(-0.737)$ & $(-2.781)$ & $(-2.934)$ & $(-4.201)$ & $(-4.154)$ \\
\hline \multirow{2}{*}{ DEBTR } & ${ }^{*}-7.338$ & $*-7.055$ & 4.519 & 5.046 & $*-10.919$ & $*-10.819$ \\
\hline & $(-1.949)$ & $(-1.841)$ & $(0.589)$ & $(0.643)$ & $(-1.903)$ & $(-1.885)$ \\
\hline \multirow{2}{*}{ FIXED } & ${ }^{*}-7.338$ & ${ }^{*}-7.055$ & 4.519 & 5.046 & *-10.919 & ${ }^{*}-10.819$ \\
\hline & $(-1.949)$ & $(-1.841)$ & $(0.589)$ & $(0.643)$ & $(-1.903)$ & $(-1.885)$ \\
\hline \multirow{2}{*}{ ATR } & $* * * 5.589$ & $* * 5.073$ & 5.822 & 4.453 & -3.449 & -3.946 \\
\hline & $(2.743)$ & $(2.429)$ & $(1.402)$ & $(1.042)$ & $(-1.332)$ & $(-1.510)$ \\
\hline \multirow{2}{*}{ LIQ } & -0.015 & -0.019 & 0.006 & -0.004 & 0.046 & 0.043 \\
\hline & $(-0.428)$ & $(-0.516)$ & $(0.082)$ & $(-0.050)$ & $(0.672)$ & $(0.622)$ \\
\hline \multirow{2}{*}{ AGE } & ${ }^{\star} 8.695$ & 7.242 & -0.546 & -3.936 & -2.249 & -2.498 \\
\hline & (1.907) & $(1.584)$ & $(-0.059)$ & $(-0.421)$ & $(-1.028)$ & $(-1.149)$ \\
\hline \multirow{2}{*}{ GDP } & -0.197 & -0.146 & 0.049 & 0.178 & 0.093 & 0.160 \\
\hline & $(-1.343)$ & $(-0.982)$ & $(0.164)$ & $(0.588)$ & $(0.343)$ & $(0.578)$ \\
\hline \multirow{2}{*}{ INFL } & $* * * 0.404$ & ${ }^{* *} 0.368$ & 0.106 & 0.016 & 0.198 & 0.174 \\
\hline & $(2.638)$ & $(2.372)$ & $(0.341)$ & $(0.052)$ & $(0.940)$ & $(0.807)$ \\
\hline Adj. $\mathrm{R}^{2}$ & 0.638 & 0.627 & 0.669 & 0.656 & 0.151 & 0.153 \\
\hline F-Value & ${ }^{* * *} 6.794$ & ${ }^{* * * 6.520}$ & $* * * 7.643$ & $* * 7.263$ & ${ }^{* * *} 4.709$ & $* \star * 4.762$ \\
\hline
\end{tabular}

Note: Beta coefficients in front of the parentheses, $t$-statistics in the parentheses; statistically significant at $10 \%$ $(*), 5 \%\left({ }^{* *}\right)$, and $1 \%\left({ }^{* *}\right)$ confidence level. 


\section{DETERMINANTE PROFITABILNOSTI POLJOPRIVREDNOG SEKTORA U} VOJVODINI: ULOGA POREZA NA DOBITAK

\section{Rezime:}

Usled značajnog učešća u ukupnoj zaposlenosti i spoljnotrgovinskoj razmeni, poljoprivreda predstavlja važan sektor ekonomije Srbije. Stoga, neophodno je kontinuirano analizirati finansijske performanse poljoprivrednih preduzeća i ključne determinante finansijskih performansi. Ciljevi rada jesu analiza opterećenja porezom na dobitak poljoprivrednih preduzeća u Vojvodini i njegovog uticaja na profitabilnost preduzeća. Statistički testovi su pokazali da su efektivne stope poreza na dobitak (ETR) u poljoprivrednim preduzećima značajno niže u odnosu na propisanu stopu poreza na dobitak. Dodatno, oko $69 \%$ opservacija ima i tekuću ETR i gotovinsku ETR od 0\%, što ukazuje na to da je poljoprivreda delatnost sa izuzetno niskim opterećenjem porezom na dobitak. Panel regresija je pokazala da su poljoprivredna preduzeća sa nižim ETR profitabilnija u odnosu na preduzeća sa višim ETR. Rezultati analize nisu senzitivni na promene merila opterećenja porezom na dobitak i profitabilnosti.

\section{Ključne reči:}

poljoprivreda, profitabilnost, porez na dobitak, Vojvodina. 